\section{Is H9N2 avian influenza virus a pandemic potential?}

\section{To the Editor:}

$\mathrm{H} 1 \mathrm{~N} 1$ and $\mathrm{H} 3 \mathrm{~N} 2$ influenza virus subtypes continue to cause human disease $(1,2)$, while avian influenza A H5 and $\mathrm{H} 7$ subtypes spread globally among birds with limited an inefficient transmission to humans $(3,4)$. Results from recent ferret research on the H9N2 subtype has demonstrated an increased theoretical threat to humans from the potential emergence of novel subtypes of avian influenza.

In North America, there is no evidence of fixed lineages of the H9N2 avian influenza virus in land-based poultry; it is found in wild ducks and shore birds (5). In contrast, H9N2 remains endemic across Asia, mainly limited to outbreaks in domestic land-based poultry, but overshadowed as a pandemic threat by $\mathrm{H} 5 \mathrm{~N} 1$ bird flu, which has spread from Asia into Africa and Europe (6-9). However, there is evidence of interspecies transmission of H9N2 from land-based poultry to mammals, such as pigs and swine (10-13). Further evidence of an expanded mammalian host range includes efficient replication of H9N2 in mice without adaptation (14). H9N2 has already caused mild respiratory disease in humans in Hong Kong and mainland China in 1999 and 2003 $(10,13,15,16)$. The six genes encoding the internal components of the H9N2 virus are similar to those found in a previous 1997 outbreak of $\mathrm{H} 5 \mathrm{~N} 1$ that caused several human deaths in Hong Kong (15). Furthermore, circulating H9N2 strains show human-like receptor specificity with amino acid leucine at position 226 at the receptorbinding site of human airway epithelial cells cultured in vitro (17). H9N2 isolated from live bird markets in Hong Kong possessed receptor specificity similar to human H3N2 viruses (18) and mutations similar to human $\mathrm{H} 2 \mathrm{~N} 2$ and $\mathrm{H} 3 \mathrm{~N} 2$ viruses, so the glycoproteins of the Hong Kong H9N2 viruses may potentially promote human infection.

In a ferret model of transmission (9), the H9N2 avian reassortment subtype appears to be evolving. The H9N2 virus replicates in the respiratory tract of ferrets and can spread to noninfected ferrets (9). The amino acid leucine residue located at position 226 in the hemagglutinin receptor-binding site (instead of glutamine), plays a key role in human virus-like receptor specificity, and promotes transmission of the H9N2 virus in ferrets. Airborne transmission has not been detected. Mixing the H9N2 viral genes containing the surface glycoprotein and the six internal genes of a human $\mathrm{H} 3 \mathrm{~N} 2$ virus resulted in increased transmissibility. The model and reassortment mixing results raises concern about viral evolution as well as efficient pandemic transmission, and suggests that the H9N2 avian virus could be of pandemic importance (19). To conclude that H9N2 is the next human pandemic strain is premature at this time given the unfolding evidence. Yet, the possibility for competent nonavian intermediate reassorters generating novel and virulent pandemic strains of H9N2 (or other avain influenza strains) has increased given the recent raccoon influenza transmission findings (20). Additional study and timely surveillance of H9N2 is needed to identify any increments in viral adaptation to human beings. Studies should consider the widespread prevalence of the $\mathrm{H} 9 \mathrm{~N} 2$ virus in poultry, and co-circulation and mixing of avian $\mathrm{H} 9 \mathrm{~N} 2$ with human $\mathrm{H} 3 \mathrm{~N} 2, \mathrm{H} 5, \mathrm{H} 7$ and other avian and mammalian viruses.

NOTE: The conclusions drawn are those of the authors and not of their organizations.

Paul E Alexander MHSc, World Health Organization,

Europe Regional Office

Prithwish De PhD, Epidemiologic Management Eु Consulting, Toronto, Ontario

Supriya Rave BSc (Hons) Health Canada,

Toronto, Ontario

\section{REFERENCES}

1. Centers for Disease Control and Prevention (CDC).

Questions and answers about influenza $\mathrm{A}(\mathrm{H} 1 \mathrm{~N} 2)$ viruses. <http://www.cdc.gov/flu/about/h1n2qa.htm\#1>

(Version current at August 18, 2008).

2. World Health Organization. Influenza. <http://www.who.int/ mediacentre/factsheets/fs211/en/index.html > (Version current at August 7, 2008).

3. Manzoor R, Sakoda Y, Sakabe S, et al. Development of a pen-site test kit for the rapid diagnosis of $\mathrm{H} 7$ highly pathogenic avian influenza. J Vet Med Sci 2008;70:557-62.

4. Wang J, Vijaykrishna D, Duan L, et al. Identification of the progenitors of Indonesian and Vietnamese avian influenza $\mathrm{A}$ (H5N1) viruses from southern China. J Virol 2008;82:3405-14.

5. Hossain MJ, Hickman D, Perez DR. Evidence of expanded host range and mammalian-associated genetic changes in a duck H9N2 influenza virus following adaptation in quail and chickens. PLoS ONE 2008;3:e3170.

6. Kim JA, Cho SH, Kim HS, Seo SH. H9N2 influenza viruses isolated from poultry in Korean live bird markets continuously evolve and cause the severe clinical signs in layers. Vet Microbiol 2006;118:169-76.

7. Alexander DJ. An overview of the epidemiology of avian influenza. Vaccine 2007;25:5637-44.

8. Alexander DJ. Summary of avian influenza activity in Europe, Asia, Africa, and Australasia, 2002-2006. Avian Dis 2007;51:161-6.

9. Wan H, Sorrell EM, Song H, et al. Replication and transmission of H9N2 influenza viruses in ferrets: Evaluation of pandemic potential. PLoS ONE 2008;3:e2923.

10. Cong YL, Pu J, Liu QF, et al. Antigenic and genetic characterization of $\mathrm{H} 9 \mathrm{~N} 2$ swine influenza viruses in China. J Gen Virol 2007;88:2035-41. 
11. Cong YL, Wang CF, Yan CM, Peng JS, Jiang ZL, Liu JH.

Swine infection with H9N2 influenza viruses in China in 2004.

Virus Genes 2008;36:461-9.

12. Yu H, Hua RH, Wei TC, et al. Isolation and genetic characterization of avian origin $\mathrm{H} 9 \mathrm{~N} 2$ influenza viruses from pigs in China. Vet Microbiol 2008;131:82-92.

13. Peiris JS, Guan Y, Markwell D, Ghose P, Webster RG, Shortridge KF. Co-circulation of avian H9N2 and contemporary "human" H3N2 influenza A viruses in pigs in southeastern China: Potential for genetic reassortment? J Virol 2001;75:9679-86.

14. Choi YK, Ozaki H, Webby RJ, et al. Continuing evolution of H9N2 influenza viruses in Southeastern China. J Virol 2004;78:8609-14.

15. Lin YP, Shaw M, Gregory V, et al. Avian-to-human transmission of H9N2 subtype influenza A viruses: Relationship between H9N2 and H5N1 human isolates. Proc Natl Acad Sci USA 2000;97:9654-8.
16. Butt KM, Smith GJ, Chen H, et al. Human infection with an avian H9N2 influenza A virus in Hong Kong in 2003. J Clin Microbiol 2005;43:5760-7.

17. Wan H, Perez DR. Amino acid 226 in the hemagglutinin of H9N2 influenza viruses determines cell tropism and replication in human airway epithelial cells. J Virol 2007;81:5181-91.

18. Matrosovich MN, Krauss S, Webster RG. H9N2 influenza A viruses from poultry in Asia have human virus-like receptor specificity. Virology 2001;281:156-62.

19. Cameron KR, Gregory V, Banks J, et al. H9N2 subtype influenza A viruses in poultry in Pakistan are closely related to the H9N2 viruses responsible for human infection in Hong Kong. Virology 2000;278:36-41.

20. Hall JS, Bentler KT, Landolt G, et al. Influenza infection in wild raccoons. Emerg Infect Dis 2008;14:1842-8 


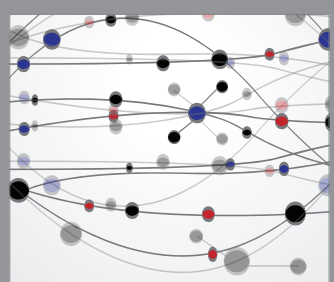

The Scientific World Journal
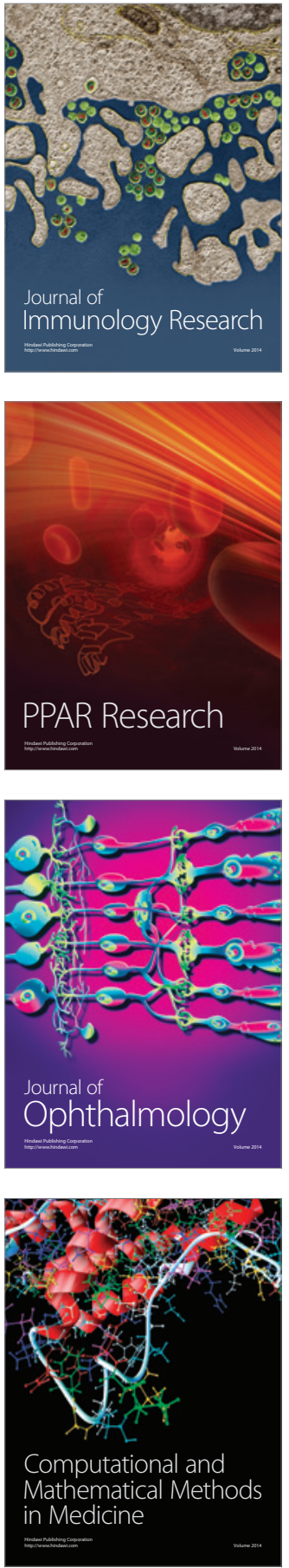

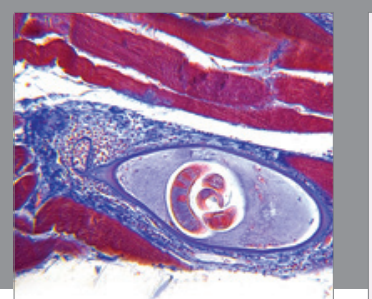

Gastroenterology Research and Practice

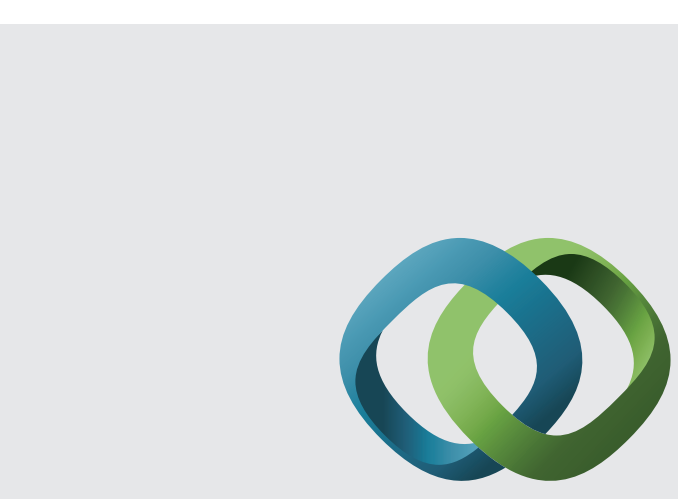

\section{Hindawi}

Submit your manuscripts at

http://www.hindawi.com
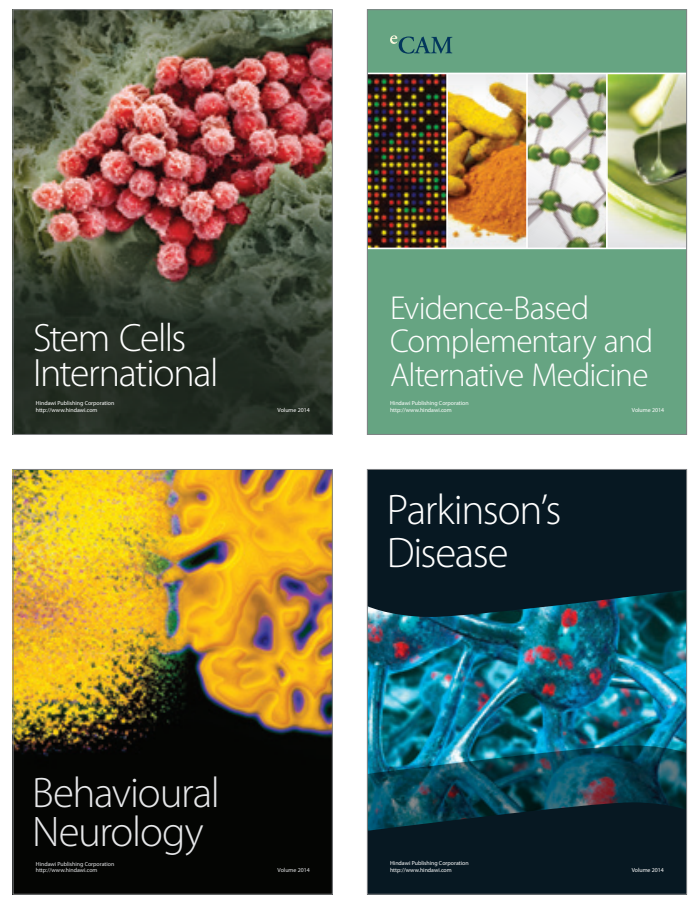
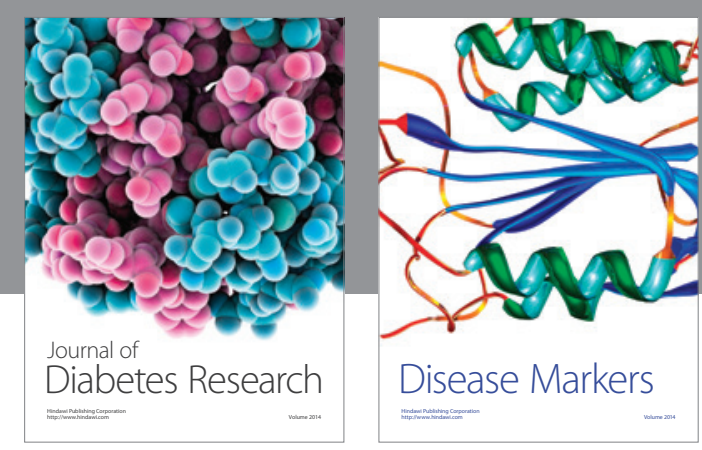

Disease Markers
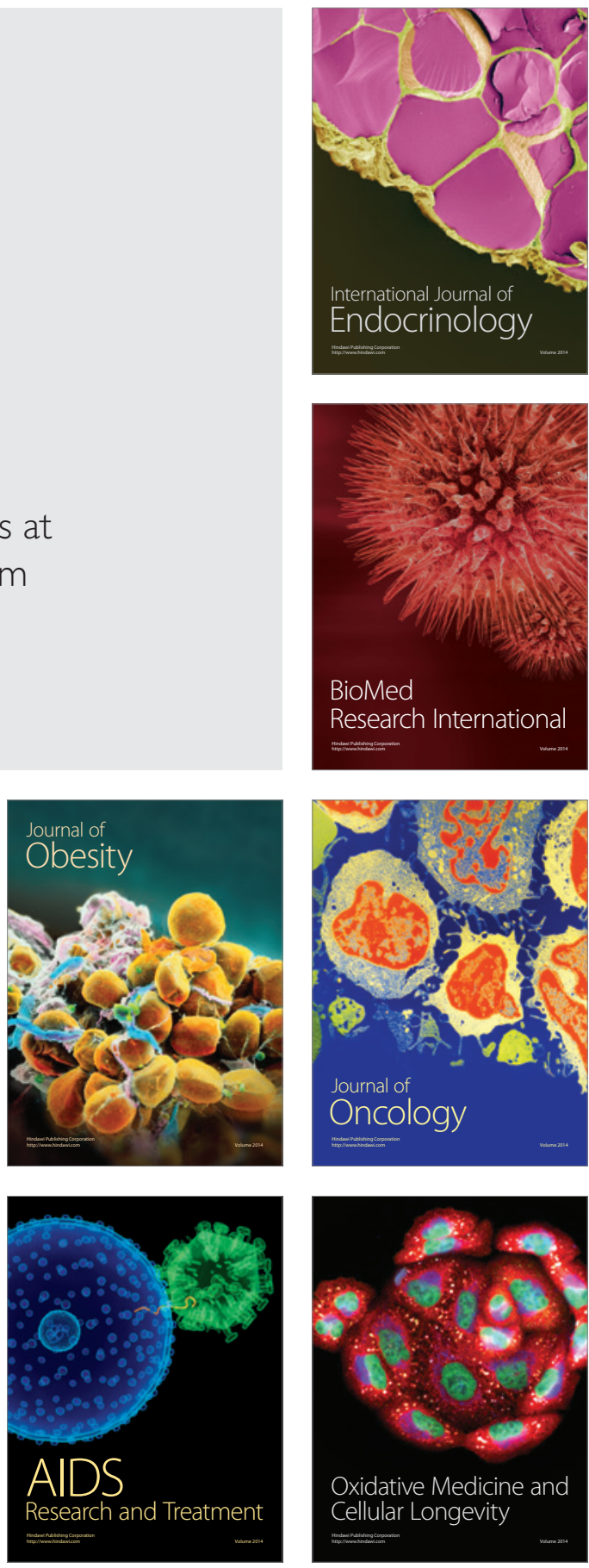